\title{
Physicochemical Characteristics of Chicken Eggshell Flour Produced by Hydrochloric Acid and Acetic Acid Extraction
}

\author{
Rosnah Rosnah $^{1 *}$, Nurpudji Astuti. Taslim², Andi Makbul Aman ${ }^{2}$, Irfan Idris ${ }^{2}$, Suryani As'ad ${ }^{2}$, Agussalim Bukhari $^{2}$, Elly Wahyudin ${ }^{3}$ \\ ${ }^{1}$ Department of Nutrition, Poltekkes Kemenkes Kendari, Kendari, Indonesia; ${ }^{2}$ Faculty of Medicine, Universitas Hasanuddin, \\ Makassar, Indonesia; ${ }^{3}$ Department of Pharmacy, Faculty of Pharmacy, Universitas Hasanuddin, Makassar, Indonesia
}

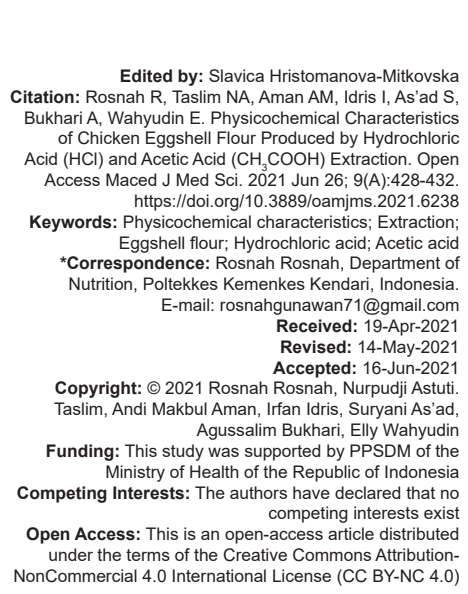

\section{Abstract}

BACKGROUND: Several previous researchers have prepared chicken eggshell flour using hydrochloric acid $(\mathrm{HCl})$ and acetic acid $(\mathrm{CH} 3 \mathrm{COOH})$ solvents. However, the results of the physicochemical characteristics still very diverse.

AIM: This study aims to produce chicken eggshell flour using two different types of solvents $(4 \% \mathrm{HCl}$ and $\mathrm{CH} 3 \mathrm{COOH}$ $2 \mathrm{~N}$ ) and determine the proper solvent to obtain better physicochemical characteristics.

METHODS: This type of research was descriptive quantitative. The research stages initiated by preparing chicken eggshell samples by maceration using $4 \% \mathrm{HCl}$ and $\mathrm{CH}_{3} \mathrm{COOH} 2 \mathrm{~N}$. Afterward, chemical characteristics (moisture content, ash, calcium carbonate, calcium, and phosphorus) and physical characteristics (yield) of eggshell flour were determined. Processing and data conducted using the IBM SPSS statistic program.

RESULTS: The higher levels of calcium, calcium carbonate, phosphorus, ash, yield, and lower water content of the eggshell powder were generated by extraction using $4 \% \mathrm{HCl}$ than $2 \mathrm{~N}$ acetic acid $\left(\mathrm{CH}_{3} \mathrm{COOH}\right)$.

CONCLUSION: The physicochemical characteristics of the eggshell powder extracted from the $4 \% \mathrm{HCl}$ were better than the $2 \mathrm{~N}$ acetic acid $\left(\mathrm{CH}_{3} \mathrm{COOH}\right)$

\section{Introduction}

Chicken eggshells as waste are mainly generated from the production of food processing industries such as cakes, bread, egg flour, frozen eggs, restaurants, households, and large-scale poultry hatcheries. In recent years, a small portion of chicken eggshells has been used as animal feed supplements, acid soil remediation, wastewater treatment, building block manufacturing, heterogeneous catalysts in biodiesel production, food supplements, cosmetics, and the pharmaceutical sector [1], [2]. However, most of the chicken eggshells worldwide are dumped in landfills which are likely to cause environmental problems [3]. The process of eggshell decomposition produces ammonia, hydrogen sulfide, and amines. Those components generate smell odors that attract mice, flies, insects, and pathogens such as Escherichia coli and Salmonella [4].

The chemical composition of eggshells consists of $1.0 \%$ protein $(\mathrm{w} / \mathrm{w}), 95 \%$ calcium carbonate (w/w) [5]; in eggshells weighing $60 \mathrm{~g}$ contains about $2.3 \mathrm{~g}$ calcium and $97 \%$ calcium carbonate [6]; contains high calcium (Ca), which is between 385 and $401 \mathrm{mg} / \mathrm{g}$, magnesium (Mg) 3.5 and $4.5 \mathrm{mg} / \mathrm{g}$ and total phosphorus
(P) 0.2 and $1.9 \mathrm{mg} / \mathrm{g}$ [1]; white chicken eggshell flour contains $113 \mathrm{mg} / \mathrm{g}$ calcium and $108 \mathrm{mg} / \mathrm{g}$ brown color [7]; calcium $2300.33 \mathrm{mg} / \mathrm{L}$, magnesium $850.00 \mathrm{mg} / \mathrm{L}$ [2]; and $99 \%$ calcium carbonate content [8]. Calcium from eggshell flour has many advantages over synthetic calcium carbonate. It is more easily absorbed in the small intestine of mice [9]. The solubility of calcium carbonate from chicken eggshells is higher than from oyster shells. Besides, the presence of valuable mineral components (strontium, barium) makes it an excellent biomaterial for the production of dietary supplements [10].

Broiler chicken eggshells can be used very effectively in a variety of applications [11]. Tablets from broiler chicken eggshell powder were tested for equality with calcium supplement CIPCAL-500 tablets from oyster shell. The source, availability, and manufacture of calcium carbonate tablets using chicken eggshells are much easier than oyster shells which are the primary source of CIPCAL-500 tablets.

The research on the kinetics of calcium release in artificial stomachs shows that calcium is released more quickly from tablets containing calcium citrate from eggshells than synthetic calcium carbonate [12]. With the many advantages and benefits of eggshells, it can be an 
alternative biomaterial that is renewable, cost-effective, and available. Poultry eggshells have a physical structure that is hard, rough, smells fishy, and has a less attractive color so that it is less desirable when used as food. Soaking using chemical solvents can improve the physical structure of the shell and reduce harmful components and remove organic compounds from the shell. One way to optimize the calcium content of eggshells is to use acetic acid [13].

An acid solution as an immersion medium initially causes complex minerals (bond with other components) to change into simple forms (ions), so they will dissolve more easily. In this case, $\mathrm{CH}_{3} \mathrm{COOH}$ acts as an enhancer, namely a molecule or compound that affects the shape and level of solubility of minerals. $\mathrm{HCl}$ is a strong acid that is least dangerous to handle than other strong acids because it contains chloride ions that are non-reactive and non-toxic. Concentrated hydrochloric acid dissolves many types of metals and produces metal chloride and hydrogen gas. It can also increase the solubility of a compound that is difficult to dissolve in water.

Each solvent has the same principle, and it will cause the shell's pores to open. Hence, the spaces may easily be reached by the solvent, which results in the compounds that bind to minerals quickly released optimally [14]. Research on the preparation of eggshell extract by extracting calcium in eggshells as calcium chloride using $4 \%$ (w/v) $\mathrm{HCl}$ solution for $3 \mathrm{~h}$ shows that the ratio of eggshell to $\mathrm{HCl}$ was 1:15 (w/v). After hydrolysis, the residue was removed by centrifugation at $\times 1774 \mathrm{~g}$ for $10 \mathrm{~min}$, and the solution was heated at $110-115^{\circ} \mathrm{C}$ until dry. The results obtained were calcium chloride powder containing $87.38 \%(\mathrm{w} / \mathrm{w})$ calcium chloride, protein $0.3 \%$, ash $94.37 \%$, and $\mathrm{pH} 5.27$ and showed high solubility [15].

Calcium from eggshells can be produced by extraction using $\mathrm{HCl}$ [16]. Calcium carbonate in eggshells will react with $\mathrm{HCl}$ to form soluble calcium chloride, $\mathrm{CO}_{2}$, and $\mathrm{H}_{2} \mathrm{O}$ gases. The best treatment was obtained from the addition of $2.5 \% \mathrm{HCl}$ concentration to produce a chicken eggshell extract with a water content of $1.19 \pm 0.06 \%$, 91\% ash, $28.17 \%$ calcium, $98.4 \% \mathrm{CaCO}_{3}$, and $0.8 \% \mathrm{Ca}_{3}\left(\mathrm{PO}_{4}\right)_{2}$ with low solubility.

Based on the background and several previous research, the physicochemical composition of chicken eggshell flour generated by hydrochloric acid $(\mathrm{HCl})$ and acetic acid $\left(\mathrm{CH}_{3} \mathrm{COOH}\right)$ is still diverse. It is necessary to find out the proper solvent that produces better chemical characteristics (moisture, ash, calcium, and phosphorus) and physical (yield) eggshell extracts.

\section{Methods}

\section{Research type and stages}

This type of research was descriptive quantitative. The research stages included preparing chicken eggshell samples and determining the chemical characteristics (moisture content, ash, calcium carbonate, calcium, and phosphorus) and physical characteristics (yield) of eggshell flour. This research was conducted in May - June 2019 at the Makassar Health Laboratory Center.

\section{Materials and tools}

The materials used in this study were chicken eggshells obtained from restaurants around the Hasanuddin University Campus in Makassar, $4 \%$ hydrochloric acid $(\mathrm{HCl}), \mathrm{CH}_{3} \mathrm{COOH} 2 \mathrm{~N}$, aquadest, and standard calcium solution. Equipment used during this study was including digital scales, basins, knives, winnowing pan, gas stove, pan, water bath, $1 \mathrm{~L}$ cup, electric oven, blender, 80 mesh filter, glass jars, electric furnaces, desiccators, porcelain cups, tube clamp, beakers, measuring flasks, Erlenmeyer, atomic absorption spectrophotometer (AAS), and UV-vis spectrophotometer.

\section{Making flour from extracts of boiler chicken eggshells}

The working method of extracting eggshell flour using a modified $4 \% \mathrm{HCl}$ solvent [11] and solvent extraction of $\mathrm{CH}_{3} \mathrm{COOH} 2 \mathrm{~N}$ from [13].

\section{solvent \\ Eggshell flour extraction using $4 \% \mathrm{HCl}$}

Boiler chicken eggshells were washed using running water, then rinsed with aquadest. Then boiled it in boiling distilled water for $15 \mathrm{~min}$, drained, and spread on a stainless steel pan, dried overnight by aerating it.

In the morning, chicken eggshells were dried in an oven at $200^{\circ} \mathrm{C}$ for $10 \mathrm{~min}$, cooled, then mashed using a blender to become a powder and then filtered with an 80 mesh sieve. Simplicia chicken eggshell powder then packed in airtight packaging, ready to be extracted.

Sample extraction was conducted by maceration method using $4 \%(\mathrm{w} / \mathrm{v})$ hydrochloric acid $(\mathrm{HCl})$ solvent to attract the chemical components for $3 \mathrm{~h}$. The comparison of the simplicity of chicken eggshells with $\mathrm{HCl}$ was 1:15 (w/v). After the sample was macerated for $3 \mathrm{~h}$, the macerate was then filtered with filter paper. The residue and $\mathrm{HCl}$ solution was removed by heating in an oven at $110-115^{\circ} \mathrm{C}$ until dry $(3 \mathrm{~h})$. After cooled, then mashed using a blender, then filtered (80 mesh), packed in airtight packaging.

\section{$2 \mathrm{~N}$ solvent}

Eggshell flour extraction using $\mathrm{CH}_{3} \mathrm{COOH}$

Chicken eggshells were washed clean, reduced in size, then immersed in aquadest at 
$100^{\circ} \mathrm{C}$ for $15 \mathrm{~min}$, drained, then added $2 \mathrm{~N}$ acetic acid $\left(\mathrm{CH}_{3} \mathrm{COOH}\right)$ (shell: solvent $=1: 2(\mathrm{w} / \mathrm{v})$ ). After, it was heated in a water bath at $60^{\circ} \mathrm{C}$ for $3 \mathrm{~h}$, removed, drained, washed with aquadest, and dried using a cabinet dryer at $\pm 50^{\circ} \mathrm{C}$ for $3 \mathrm{~h}$. After chilling, mashed in a blender and filtered using an 80 mesh sieve, packed in airtight packaging.

\section{Analysis of physicochemical characteristics}

Methods for analyzing water content (AOAC, 925.09, 2005), ash content (AOAC, 941.12, 2005), calcium carbonate (AOAC, 2005), calcium (AOAC, 968.08, 2005) using AAS at $\lambda=422,7 \mathrm{~nm}$, phosphorus (AOAC, 948.09, 2005) using a UV-vis spectrophotometer at $\lambda=660 \mathrm{~nm}$, and yield (AOAC, 2005). Measurement of the chemical characteristics of the eggshell extract was carried out in a triplo.

\section{Data analysis}

Processing and data analysis was conducted using the IBM SPSS statistics program.

\section{Results and Discussion}

The results of making eggshell extracts of broiler chickens using $2 \mathrm{~N}$ acetic acid $\left(\mathrm{CH}_{3} \mathrm{COOH}\right)$ and $4 \%$ hydrochloric acid $(\mathrm{HCl})$ solvents can be seen in Figure 1.

The average physicochemical characteristics of chicken eggshell powder extracted by $2 \mathrm{~N}$ acetic acid $\left(\mathrm{CH}_{3} \mathrm{COOH}\right)$ and $4 \%$ hydrochloric acid $(\mathrm{HCl})$ can be seen in Table 1.
Table 1: Physicochemical characteristics broiler eggs eggshell extract solvent extraction results $\mathrm{HCl} 4 \%$ and $2 \mathrm{~N} \mathrm{CH} 3 \mathrm{COOH}$

\begin{tabular}{lll}
\hline Parameter (\%) & \multicolumn{2}{l}{ Mean $\pm \mathrm{SD}$} \\
\cline { 2 - 3 } & $\mathrm{HCl} 4 \%$ & $\mathrm{CH}_{3} \mathrm{COOH} 2 \mathrm{~N}$ \\
\hline Calcium & $35.46 \pm 2.04$ & $27.41 \pm 2.56$ \\
$\mathrm{CaCO}_{3}$ & $95.54 \pm 1.16$ & $94.75 \pm 2.28$ \\
Phosphor & $0.61 \pm 0.04$ & $0.52 \pm 0.08$ \\
Water & $0.58 \pm 0.06$ & $0.75 \pm 0.72$ \\
Ash & $86.48 \pm 0.62$ & $79.18 \pm 1.27$ \\
Rendement & 81.24 & 75.33 \\
\hline
\end{tabular}

\section{Moisture content (AOAC, 925.09, 2005)}

The water content of the eggshells extracted from the $4 \% \mathrm{HCl}(0.58 \% \pm 0.06)$ was lower than that of the $\mathrm{CH}_{3} \mathrm{COOH} 2 \mathrm{~N}(0.75 \% \pm 0.72)$. The addition of $2.5 \% \mathrm{HCl}$ concentration resulted in chicken eggshell flour with a water content of $1.19 \pm 0.06 \%$ [16]. The water content of chicken shells was $0.95 \pm 0.09 \%$ [2] The shell characteristics caused the relatively low water content of the eggshells flour has a dense texture and is composed of lime. Low water content in the resulting chicken eggshell flour can extend shelf life with good quality. High moisture content tends to promote microbial contamination and chemical degradation in many substances [17].

\section{Ash content (AOAC, 941.12, 2005)}

The ash content of the eggshells from the $4 \% \mathrm{HCl}$ extraction was higher $(86.48 \% \pm 0.62)$ than $\mathrm{CH}_{3} \mathrm{COOH} 2 \mathrm{~N}$ extraction $(79.18 \% \pm 1.27)$. Eggshell flour extracted by $4 \% \mathrm{HCl}$ had an ash content of $94.37 \%$ [15]. The addition of $2.5 \% \mathrm{HCl}$ concentration resulted in chicken eggshell flour with an ash content of $91 \%$ [16]. The results of this study are different from the results of other studies reveal the ash content of chicken eggshells of $45.29 \pm 0.06 \%$ [2] .

The ash content of the material shows the number of minerals in that material. The ash content is influenced by the type of shell used as the raw material.

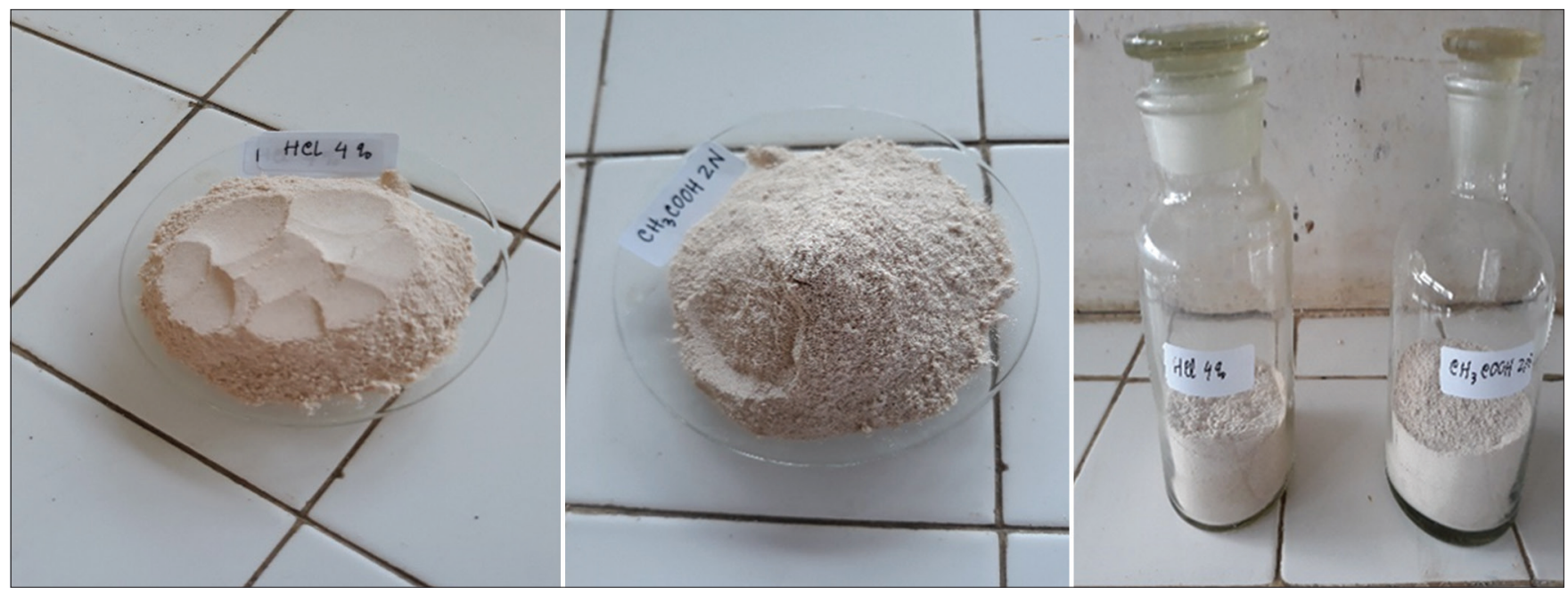

Figure 1: Extract of chicken eggshell from maceration of $4 \% \mathrm{HCl}$ and $\left.\mathrm{CH}_{3} \mathrm{COOH}\right)_{2} \mathrm{~N}$ 
Ash content measures the total amount of inorganic compounds such as minerals in eggshells [17]; [18]. The high ash content in the eggshell flour is thought to be caused by the high mineral content. In eggshells, there is calcium $\left(\mathrm{CaCO}_{3}\right)$ as the main constituent of eggshells.

\section{Calcium carbonate levels}

Calcium carbonate in the eggshell of broilers from the extraction of $4 \% \mathrm{HCl}$ was higher $(95.54 \% \pm 1.16)$ than the extract from $\mathrm{CH}_{3} \mathrm{COOH} 2 \mathrm{~N}(94.75 \% \pm 2.28)$. Eggshell flour extracted from $\mathrm{HCl} 4 \%$ had a calcium chloride content of $87.38 \%$ (w/w) [15]. The addition of $2.5 \% \mathrm{HCl}$ concentration resulted in chicken eggshell flour with $98.4 \%$ calcium carbonate $\mathrm{CaCO}_{3}$ content [16]. Eggshell flour extracted by $4 \% \mathrm{HCl}$ had a calcium carbonate content of $85 \%$ [11].

\section{Calcium levels (AOAC, 2005)}

The calcium content of the eggshell from the extraction of the $4 \% \mathrm{HCl}$ was higher $(35.46 \% \pm 2.04)$ than $\mathrm{CH}_{3} \mathrm{COOH} 2 \mathrm{~N}(27.41 \% \pm 2.56)$. The addition of $2.5 \% \mathrm{HCl}$ concentration resulted in chicken eggshell flour with a calcium content of $28.17 \%$ [16]. Eggshell flour extracted by $4 \% \mathrm{HCl}$ had a calcium content of $38 \%$ [11]. Chicken eggshell flour extracted from $\mathrm{CH}_{3} \mathrm{COOH} 2 \mathrm{~N}$ had different calcium levels of $20.67 \%$ and $6.41 \%$ [13]

Research on the comparison of calcium levels from various poultry eggshells shows that the average calcium content of poultry eggs extracted with acetic acid ranges from 20.67 to $25.73 \%$ [19]. The research results on calcium testing using the AAS method showed that in $100 \mathrm{~g}$ of eggshell flour, there was $7.2 \mathrm{~g}$ of calcium (7.2\%) [20], [21]. Calcium from eggshells consists of $98.4 \%$ $\mathrm{CaCO}_{3}$ and $0.8 \% \mathrm{Ca}_{3}\left(\mathrm{PO}_{4}\right)_{2}$ with low solubility [16]. The high content of calcium in chicken eggshells is expected to meet the calcium needed by the living body through fortification and supplementation [22].

\section{Phosphorus (P) content}

The phosphorus content of chicken eggshells extracted from $4 \% \mathrm{HCl}(0.61 \% \pm 0.04)$ was higher than that of $\mathrm{CH}_{3} \mathrm{COOH} 2 \mathrm{~N}(0.52 \% \pm 0.08)$. The addition of a $2.5 \% \mathrm{HCl}$ resulted in chicken eggshell flour with a $\mathrm{Ca}_{3}\left(\mathrm{PO}_{4}\right)_{2}$ content of $0.8 \%$ [16]. Chicken eggshells consist primarily of calcium carbonate and a small portion of phosphate. Phosphorus is not formed freely in nature and is available in the form of phosphates and orthophosphates. Phosphorus is a mineral that is relatively abundant in the animal body.

Phosphorus is the second most abundant mineral after calcium in the body and, together with calcium, is bound in the bone framework. The relationship between calcium and phosphorus in plasma has a very significant correlation, which is 0.998 . The ratio of calcium and phosphorus to plasma for bone formation ranges from 1.5: 1 . The results of this study indicated the ratio of $\mathrm{Ca}$ : $\mathrm{P}$ for the extraction of $\mathrm{HCl}$ $4 \%=35.46 \% \pm 2.04: 0.61 \% \pm 0.04$, while the extraction of $\mathrm{CH}_{3} \mathrm{COOH} 2 \mathrm{~N}$ yields a ratio of $\mathrm{Ca}$ : $\mathrm{P}=27.41 \% \pm$ 2.56: $0.52 \% \pm 0.08$.

\section{Yield (AOAC 2005)}

The yield is the percentage of eggshell flour calculated based on the ratio between the eggshell flour produced and the weight of raw materials (chicken eggshells) that have been cleaned. The more yields are produced, the more efficient the treatment is applied. This study obtained the yield value of chicken eggshell powder extracted from $4 \% \mathrm{HCl}$ was higher $(81.24 \%)$ than $\mathrm{CH}_{3} \mathrm{COOH} 2 \mathrm{~N}(75.33 \%)$

The results of other studies showed that the average yield of eggshell flour extracted with acetic acid $\left(\mathrm{CH}_{3} \mathrm{COOH} 2 \mathrm{~N}\right)$ ranged from $68.97 \%$ to $88.83 \%$ [13]. Processing of poultry eggshells into shell flour by immersion method (distilled water, $\mathrm{HCl}, \mathrm{CH}_{3} \mathrm{COOH}$, and $\mathrm{NaOH}$ ) had a high yield, ranging from $78.37 \%$ to $98.62 \%$ [19].

\section{Conclusion}

The chemical and physical characteristics of chicken eggshell powder extracted by $4 \% \mathrm{HCl}$ were better than $2 \mathrm{~N}$ acetic acid $\left(\mathrm{CH}_{3} \mathrm{COOH}\right)$. It can be seen from the higher levels of calcium, calcium carbonate, phosphorus, ash, yield, and lower water content than the eggshell flour extracted by $4 \% \mathrm{HCl}$ compared to the $2 \mathrm{~N}$ of acetic acid $\left(\mathrm{CH}_{3} \mathrm{COOH}\right)$.

\section{References}

1. Schaafsma A, Pakan I, Hofstede GJ, Muskiet FA Van Der Veer E, De Vries PJ. Mineral, amino acid, and hormonal composition of chicken eggshell powder and the evaluation of its use in human nutrition. Poult Sci. 2000;79(12):1833-8. https://doi.org/10.1093/ps/79.12.1833

PMid:11194049

2. Ajala EO, Eletta O, Ajala MA, Oyeniyi SK. Characterization and evaluation of chicken eggshell for use as a bio-resource. Arid Zone J Eng Technol Environ. 2018;14(1):26-40.

3. Hart A. Mini-review of waste shell-derived materials applications. Waste Manage Res. 2020;38(5):514-27. https:// doi.org/10.1177/0734242×19897812 PMid:31928177

4. Owuamanam S, Cree D. Progress of bio-calcium carbonate waste eggshell and seashell fillers in polymer composites: 
A review. J Composit Sci. 2020;4(2):70. https://doi.org/10.3390/ jcs4020070

5. Daengprok W, Naivikul O, Pornsinlpatip P, Issigonis K. Chicken eggshell matrix proteins enhance calcium transport in the human intestinal epithelial cells, Caco-2. J Agric Food Chem. 2003;51(20):6056-61. https://doi.org/10.1021/jf034261e PMid:13129316

6. Hunton P. Research on eggshell structure and quality. Braz $J$ Poult Sci. 2005;7(2):67-71.

7. Ali M, Badawy W. Utilization of eggshells by-product as a mineral source for fortification of bread strips. J Food Dairy Sci. 2017;8(11):455-9. https://doi.org/10.21608/jfds.2017.38960

8. Domrongpokkaphan V, Khemkhao M. Calcium chloride produced from eggshell for vegetable washing. J App Sci. 2017;16(2):1-7. https://doi.org/10.14416/j.appsci.2017.09.001

9. Omi N, Ezawa I. Effect of egg-shell ca on preventing of bone loss after ovariectomy. J Home Econ Jpn. 1998;49(3):277-82.

10. Szeleszczuk $Ł$, Pisklak DM, Kuras M, Wawer I. In vitro dissolution of calcium carbonate from the chicken eggshell: A study of calcium bioavailability. Int J Food Propert. 2015;18(12):2791-9. https://doi.org/10.1080/10942912.2015.1004587

11. Chakraborty MA. Chicken eggshell as calcium supplement tablet. Int J Sci Eng Manage. 2016;1(5):45-9.

12. Barbara D, Marta J, Beata SM, Florian R. Use of eggshells as a raw material for production of calcium preparations. Czech J Food Sci. 2017;34(4):313-7. https://doi.org/10.17221/59/2016-cjfs

13. Aminah S, Meikawati W. Calcium content and flour yield of poultry eggshell with acetic acid extraction. In: The $4^{\text {th }}$ University Research Colloquium (URECOL). Surakarta: Universitas Muhammadiyah Surakarta; 2016. p. 49-53. Available from: http://www.publikasiilmiah.ums.ac.id/handle/11617/7741. [Last accessed on 2021 May 15].

14. Suptijah P, Jacoeb AM, Deviyanti N. Karakterisasi dan bioavailabilitas nanokalsium cangkang udang vannamei (Litopenaeus vannamei). J Akuatika. 2012;3(1):63-73.

15. Garnjanagoonchorn W, Changpuak A. Preparation and partial characterization of eggshell calcium chloride. Int J Food Propert. 2007;10(3):497-503. https://doi. org/10.1080/10942910600919484

16. Gongruttananun N. Effects of eggshell calcium on productive performance, plasma calcium, bone mineralization, and gonadal characteristics in laying hens. Poult Sci. 2011;90(2):524-9. https://doi.org/10.3382/ps.2010-01003

PMid:21248354

17. Ooi DJ, Iqbal S, Ismail M. Proximate composition, nutritional attributes and mineral composition of Peperomia pellucida L. (ketumpangan air) grown in Malaysia. Molecules. 2012;17(9):11139-45. https://doi.org/10.3390/ molecules170911139

PMid:22986924

18. Segura-Campos M, Pérez-Hernández R, Chel-Guerrero L, Castellanos-Ruelas A, Gallegos-Tintoré S, Betancur-Ancona D. Physicochemical and functional properties of dehydrated Japanese quail (Coturnix japonica) egg white. Food Nutr Sci. 2013;4(3):289-98. https://doi.org/10.4236/fns.2013.43039

19. Yonata D, Aminah S, Hersoelistyorini W. Kadar kalsium dan karakteristik fisik tepung cangkang telur unggas dengan perendaman berbagai pelarut calcium. J Pangan Dan Gizi. 2017;7:82-93. https://doi.org/10.26714/jpg.10.1.2020.18-23

20. Safitri Al, Muslihah SW. Kajian penambahan tepung cangkang telur ayam ras terhadap kadar kalsium, viskositas, dan mutu organoleptik susu kedelai. Majalah Kesehatan FKUB. 2014;1:149-60. https://doi.org/10.23917/jk.v6i1.5565

21. Taslim NA, Rasyid H, Atmanegara MK, Angriavan S, Amelia R. Effect of chocolate soybean drink on nutritional status, gamma interferon, Vitamin $\mathrm{D}$, and calcium in newly lung tuberculosis patients. Open Access Maced J Med Sci. 2020;8(T2):210-4. https://doi.org/10.3889/oamjms.2020.5233

22. Amelia R, Taslim NA, Citrakesumasari C. The effects of soybean chocolate drink treatment on the calcium levels in patients with pulmonary tuberculosis. IJPHRD. 2019;10(4):869-73. 